\title{
Legacies and Gifts
}

FPS is most grateful for the following gifts of $£^{20}$ and over, as well as many smaller ones, totalling $£ 16,668$, received between September 1978 and February 15 1979:

\section{Legacies}

Miss Hilda Tilley

Miss C. K. McMullen

$£ 4839$

$f^{500}$

\section{Gifts}

BBC Nationwide 'Save Our Species' Programme

$£ 2734$

Anonymous

$£ 2000$

New Moorgate Trust

$£ 1000$

St Katharine's Fund

J. Constable, Mrs. M. J. Hayne, each

F. Hammer

$£ 400$

$£ 100$

Mrs R. H. Taylor

Miss E. Hickok

Oryx 100\% Fund

People's Trust for Endangered Species

(earmarked for Greenpeace grey seal campaign)

$£ 4000$

St Katharine's Fund

(earmarked for East African Wildlife Society)

Thomas Lilley Memorial Trust

Lt Col A. E. Gibbs, Brigadier E. F. Maude, K. Richards, each

J. C. Cadbury, M. Fitter, S. Rostron, each

\section{Oryx $100 \%$ Fund}

The following grants have been made from the FPS Oryx $100 \%$ Fund:

f500 to Dr C. M. Perrins to study the fauna of Gran Chaco, Argentina.

$£ 500$ to Peru's Pro Defensa de la Naturaleza to buy equipment for the Paracas Institute, Lima, Peru.

$£ 300$ to Jane Whitten to complete a study of the endemic small mammals of Siberut Island in Indonesia.

$£ 250$ to the Charles Darwin Foundation in the Galapagos for a study of the dark-rumped petrel.

$£ 295$ for insignia for vehicles belonging to the Rwandan Office of Tourism and National Parks.

$£ 250$ to Jesus Garzon to study biotype preservation on the Tagus River in Spain.

$£ 250$ to David Jones for an ecological survey of the Massif du Termit in Niger.

$£ 200$ to William J. Higgs for a study of Greenland white-fronted geese.

$£ 175$ to $M$. A. Linley of the University of Bristol for a status study of lizards on Hierro in the Canary Islands.

$£ 150$ to Dr N. J.Collar of the Edward Grey Institute for an ICBP expedition to the Canary Islands to study the houbara bustard.

$£ 100$ to Zafar Futehally to organise the Conservation Symposium of the International Primatological Congress in Bangalore, India, January 1979. 